University for Business and Technology in Kosovo

UBT Knowledge Center

UBT International Conference

2013 UBT International Conference

Nov 2nd, 3:15 PM - 3:30 PM

\title{
Analogy in elements: breaking the national identity
}

Kujtim Elezi

State University of Tetova

Nuran Saliu

State University of Tetova

Follow this and additional works at: https://knowledgecenter.ubt-uni.net/conference

Part of the Architecture Commons

\section{Recommended Citation}

Elezi, Kujtim and Saliu, Nuran, "Analogy in elements: breaking the national identity" (2013). UBT

International Conference. 23.

https://knowledgecenter.ubt-uni.net/conference/2013/all-events/23

This Event is brought to you for free and open access by the Publication and Journals at UBT Knowledge Center. It has been accepted for inclusion in UBT International Conference by an authorized administrator of UBT Knowledge Center. For more information, please contact knowledge.center@ubt-uni.net. 


\title{
Analogy in elements: breaking the national identity
}

\author{
Kujtim Elezi ${ }^{1}$, Nuran Saliu1 \\ ${ }^{1}$ State University of Tetova, Faculty of Applied Sciences, Republic of Macedonia, University \\ Rectorate
}

\begin{abstract}
Abs tract. The first aim of this paper is to present the after W.W.II temptation of the Macedonian authors to identify national elements that is Macedonian elements in houses build in Macedonia. After identifying them, the same elements (now national) will be used to declare the national heritage in Macedonian houses. Secondly, we would like to compare the same elements found as Macedonian with other places, like Turkey (involving Bursa, Istanbul and other cities), to see if they really are different as those from houses in Turkey, or there is a similarity between them.
\end{abstract}

Keywords: tradition, identity, his tory of architecture.

\section{Introduction}

The year of ' 49 marks the beginning of the search for national elements in houses build in Macedonia, when a Slovenian born architect Dusan Grabrijan will be called to make a study trip to Macedonia and identify Macedonian national elements in houses build in the late $19^{\text {th }}$ century and begin of the $20^{\text {th }}$ century. Grabrijan, and after him other Macedonian authors, not only will identify Macedonian national elements in houses build in Macedonia, but moreover will speak about the analogy between Le Corbusier and houses build in Macedonia; the Macedonian influence on Le Corbusier and the importance of the national architecture in Macedonia for the modern movement. One might be satis fied and might believe in all what was written about these topics, only when one side of the story is taken for granted. On the other side, if we compare houses build in Macedonia with those build in Turkey, we hardly can find the difference between their elements.

\section{National elements in architecture}

It can be said that all the authors that worked and studied profane architecture of the end of $19^{\text {th }}$ century and the beggining of $20^{\text {th }}$ century in territories of Macedonia were lucky, because after the Second World War they would find the full 'dough'and almost intact from war. As a start let us mention the study done by Aleksandar Deroko, whose work (Narodno Neimarstvo I, II, Naućno Delo, Beograd, 1968). presents the real situation of different cities across Yugoslavia, were a part of the contents will make the presentation of the situation in Macedonia (Deroko 1968). Deroko's work, if it was not for thorough and rational analysis of urban and architectural solutions of old city houses, it will be important for presenting inf form of photographs for many buildings, which very soon will leave place to new interventions, mainly done in name of modernism that was belatedly embraced. It seems that the given denomination 'People's Architecture' is general one, or better said all-embracing one, because the term national(people's) would be included buildings from south of Macedonia to north of Slovenia. Above all, this universal denomination was not revealing the macedonian identity in architecture. Therefore, later we observe that macedonian researchers reveal desire to present what was built in Macedonia initially exclusively macedonian, and later as national. It is worth mentioning local authors, who will intentionally guide their studies towards identifying macedonian elements in the architecture of houses, and the national character expressed through architecture. Sotir Tomoski, describes the whole value of the Macedonian house. He names the chardak as the most important element of the house, around which the anonimous master organizes other rooms (Tomoski 1960). According to Tomoski, the chardak is the heart of the Macedonian house, it is the place where one relaxes and has the possibility of the good view. Standing in the chardak makes you believe one is up in the air. Further, Tomoski talks about the two storey level that the house has, than the flexibility of the floors, where he discovers that every flor 
can be (or is) organized differently compaired with other ones. The great number of windows designed and build close to each other is another element that vecon the Macedonian house from that of the Orient. Indeed, according to Tomoski the Macedonian house is open to the public, that is street, has nothing to hide inside. Another key element named as Macedonian is the geometry of the house itself, where, due to the terrain complexities the ground floor is very small, and above the ground floor the master in Macedonia us es the console, the erker and the chardak as elements that would settle order in the geometry of the floor, and makes the first or the second floor bigger, compaired to the ground floor. More specifically, Tomoski suggests that, "These [Macedonian] houses are the ancestors of modern architecture..." (Tomoski 1960) Krum Tomoski, in his 1966 work 'Dejnosta na majstorite graditeli od Debar'(The Creativity of the Master Builders of Dibra) did not discuss the qualities of Macedonian nineteenth century architecture, and instead occupied himself with the "identification" of the masters builders from this period. Of all the achievements in the sphere of nineteenth-century architecture in Macedonia, he concentrated on the master builders from the city of Dibra and the surrounding region. According to Krum Tomovski, Dibra's master builders built not only in Macedonia but in the whole area of the Balkans and Asia Minor. The proverb "If Istanbul is destroyed, Dibra will re-built it, but if Dibra is destroyed even Istanbul cannot rebuilt it" is said to prove the importance of the "Dibra School" in the whole region of the Balkans during the nineteenth century.

Boris Cipan in his 'Starata gradska arhitektura vo Ohrid' (Old Town Architecture in Ohrid), lists the characteristics of the nineteenth century architecture in Macedonia. He claims that Macedonian houses have separated the functions in the house floors, such the ground floor contents the working place, storage rooms, and other floors, one or two are reserved for the dwelling or living purposes, in short in summer and winter living areas. Čipan explains: "The creative capability of the master builder, with which he solves this problem, has as a result an architecture that is entirely humanized, setting the master builder from Ohrid close to the protagonists of modern architecture."(Čipan 1982). Elsewhere in his book Čipan argues that the Bondruk structural system allowed the master builder great flexibility and freedom in planning the floors and the facades. Sometime later, Jasmina Haxhieva-Aleksievska argued in her 1984 book Merki, antropomorfnost i modularni proporcii kaj starata Makedonska kukja (Measures, anthropomorphism and modular proportions in the old Macedonian house) that the anonymous master builder stays very close to the modernists in applying mathematical and geometrical ordering principles in his architecture. In analyzing houses from almost all cities in Macedonia, Haxhieva-Aleksievska discovers that geometrical and numerical methods, such as "square decomposition" the "Pythagorean theorem", the "Golden Section" and the "Fibonacci series" have been used in vernacular architecture in Macedonia (Haxhieva-Aleksievska 1984). She claims that this was not a coincidence, because there are too many examples of buildings that conform to one of these systems. Instead of chance, the use of these theorems has to have been some sort of "education" during which the anonymous master builders went through (Haxhieva-Aleksievska 1984). She found little difference between the Arshin, a proportional system allegedly used by the master builders of Dibra, and Le Corbusier's Modulor. The Arshin comprises of the sequence: $28,5 \mathrm{~cm}-47,5 \mathrm{~cm}-76 \mathrm{~cm}-84,5$ $\mathrm{cm}-114 \mathrm{~cm}-180,5 \mathrm{~cm}-228 \mathrm{~cm}$, while Le Corbusier's Modulor proscribes the dimensions $27 \mathrm{~cm}-43$ $\mathrm{cm}-70 \mathrm{~cm}-86 \mathrm{~cm}-113 \mathrm{~cm}-183 \mathrm{~cm}-226 \mathrm{~cm}$. Marula Nikoloska is worth to be mentioned here for the various examples of the houses in the city of Krusevo. In her study, Prostorna organizacija gradske kukje XIX veka u Makedoniji (a Doctoral thesis), Nikoloska shows the importance of the dwelling process, the role of the chardak in the house of Kruševo, and different solution of the floors, based most likely on the complexity of the terrain. The soul of the Macedonian house it can be followed in the descriptions of another native author Petar Mulick oski. Mulićkoski in his book claims that the soul ofa nation can be read from the architecture it produces (Mulickoski 2000). However, he points out that Macedonian architecture can't be represented solely by the architecture of the nineteenth century for the Macedonian way of dwelling reaches back to antiquity. Based on its particular qualities, Mulićkoski claims that the Macedonian house can be compared with other "well known models from around the world" such as the Pompeian house, and dwellings from Japan and China (Mulickoski 2000). However, as a bible of the Macedonian house will count a publication of a not native author- Dušan Grabrijan. Published in 1955, Makedonska kuća [The Macedonian House] presents all of what Grabrijan had investigated and found interesting in Macedonia back in 1949. One of the first issues to be discussed in the book concerns house typologies. Basing on examples from the region, Grabrijan distinguishes two basic house types in Macedonia: 1. Velesi or "low" type; and 2. Ohrid or "high" type (Grabrijan 1955). 
Grabrijan argues that due to the climate in Macedonia there is a division of the living areas through the different levels of the house; the winter living areas organized on the massive ground floor constructed of stone, and in the summer living areas organized on the upper floor constructed of a wooden frame, and organized around the chardak, which may be open or closed, depending on the climate. The human scale of the rooms in a Macedonian house is expressed, Grabrijan argues, by the changing floor levels, which create varying heights in the rooms. In contrast to other rooms, the chardak, and sometimes the trem, occupy a two-storey space. All dimensions are quite small, and rooms gain life only through the presence of man. According to Grabrijan, the external appearance of the house is also enlivened through habitation, thus lending a harmonious quality to the entire structure. For Grabrijan, the human scale of these houses makes them homey, intimate and human.

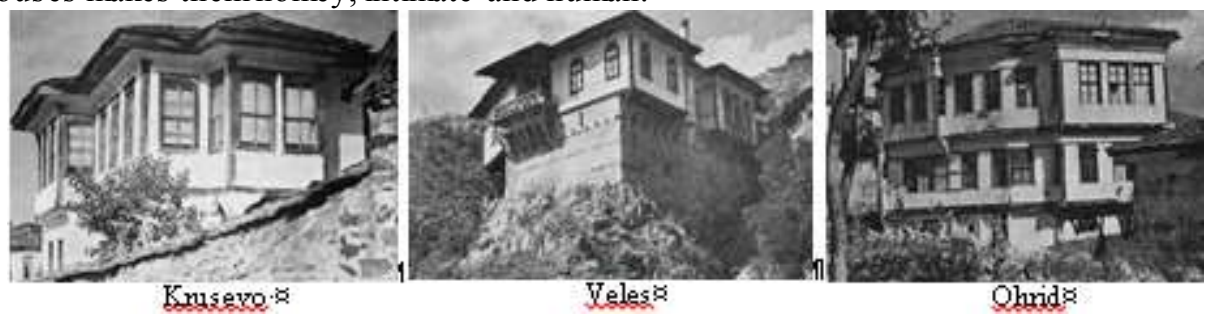

Fig.1. Grabrijan's Photographs of Macedonian Houses

However, what gave the book special importance are two of Grabrijan's conclusions. Firstly, he argues that Macedonia, thanks to its geographical location, mediates between two entirely different cultures, simply because the Macedonians never totally relinquished their European way of living and were always able to respond to newly emerging needs (Grabrijan 1955). Grabrijan concludes that the Macedonian house presents a transition from the traditional Oriental to the modern European house.

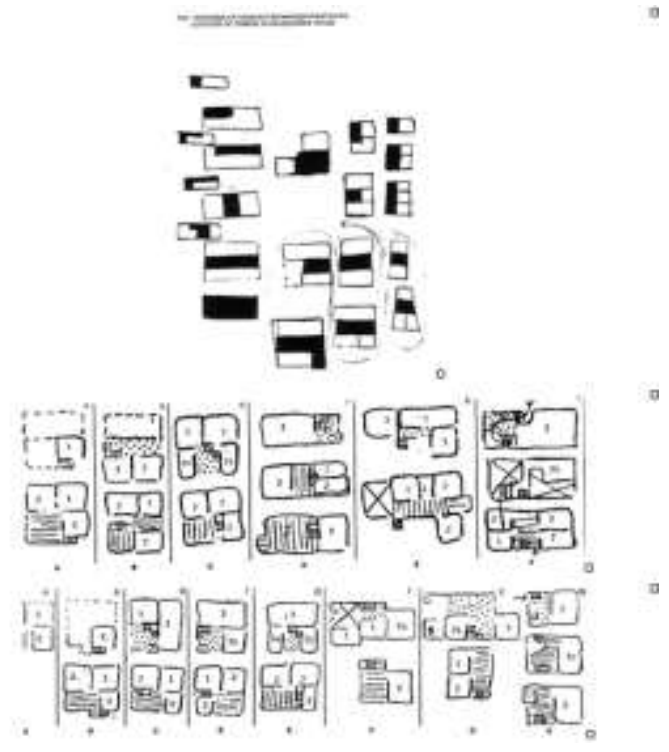

Fig 2. The matrix of planimetric organizations of Macedonian house according to Grabrijan (1955)

Secondly, Grabrijan claims that the nineteenth century architecture of Macedonia follows "modern architectural principles." Grabrijan sees the Macedonian house as a dialogue between "Oriental" and "modern" architectural thinking. "Human scale", "plasticity of spaces", "flexibility", "unobstructed views", and "geometry" were the modern principles he discovered in the Macedonian house (Grabrijan 1955). He believed it was very hard to dismiss the links between the modern and Macedonian house. As an energetic protagonist of progressive architecture, Grabrijan unveiled in the Macedonian architectural heritage a source of creative inspiration for contemporary architecture. 


\subsection{Conclusion}

Going after the above quoted authors, one comes to the conclusion that elements, such as the presence of the chardak as a house element, the asymmetry of the first floor, the geometry of the second and third floor, the look of the house to the street, their openness and lightness, the erker, the console, the bondruk structure, the human scale, the two story level (the gallery), the trem, flexibility of the floor planning, its space full of plasticity, are recognizable Macedonian elements that id entify the Macedonian character of the House itself, build in Macedonia during the late 19th and the begin of the 20th century. The chosen elements, identified as Macedonian by different authors in Macedonia, will help them to express the dose of nationalism in architecture at that time, building this way their identity through architecture. The dose of Nationalism looking to be expressed in architecture, confirms the desire of the Macedonians to build the image of identity.

\section{International Recognition, Le Corbusier read by Grabriijan}

Grabrijan not only was the best example of explaining the meaning and the value of the Macedonian house, but also he will go a step further- that of international recognition of the Macedonian house. The Internationalization of the Macedonian house Grabrijan has achieved comparing the houses he discovered, studied and analyzed in Macedonia with the work of the most recognized Century architectLe Corbusier.

Grabrijan is deeply convinced there is an analogy between the Macedonian house and Le Corbusier's villas. "I would like to discuss the analogy between the Macedonian house and the modern one. Maybe this analogy seems strange to you." He continues: "Maybe, but only at first, because one is used to hear discussions about the analogy between Le Corbusier and the Oriental house, which at some point withstands scrutiny, but never about the analogy between Le Corbusier and the Macedonian house, simply because here things are a little more sensitive". "After all the parallels presented," Grabrijan insists, "no one can deny the influence of the Macedonian house on Le Corbusier's language of architecture." (Grabrijan 1955).

\subsection{Bondruk versus Dom-Ino}

For Grabrijan, the most important element in the Macedonian house is its wooden structure, known as the Bondruk. For Grabrijan, the Bondruk system exhibits a logical structural concept; light and adaptable, it is a structure that offers very broad functional and organizational possibilities. Moreover, the Bondruk is said to be analogous to Le Corbusier's Dom-Ino: "The only difference between the structures is in the materials used; here [in Macedonia] it is wood, while Le Corbusier uses the béton armé." (Grabrijan 1955). According to Grabrijan, the columns that support a slab of wood open up the possibility of organizing the each floor independently of the others. Walls need to rest upon those below but they can be freely built where they are most needed, they can meander about or be eliminated altogether if more space is required. Likewise, different functions are possible on each level. Grabrijan states: "It wouldn't be incorrect to compare this with Le Corbusier's Plan libre" Grabrijan thinks that the structure also makes it possible for the walls to include open windows in rows, or even for the whole wall to be replaced by windows. "With such a construction, we can open windows everywhere in the wall structure, or the walls can even be completely eliminated. With such a structure, the possibility arises to organize the interior space as one wishes, to model the façade and to open windows in walls. Like it or not," continues Grabrijan, "I come to think here of Le Corbusier's façade libre and fenetre en longueur."(Grabrijan 1955).

\subsection{Erker in Macedonia}

The flexibility offered by the Bondruk structure is not limited only to the planning of the floors and facades. Grabrijan also finds attractive the potential the structure gives the master builders to correct the irregularity of the ground floor plan on the first floor, to enlarge the area of the first floor during the process of correction, and to practice the cantilever. From his comments on houses from Ohrid, Struga 
and Velesi we see that Grabrijan admires the "oriel principle" "These floors", writes Grabrijan, "thanks to the use of the oriel principle, are hung like boxes in the air. The first architectural visitors to Macedonia used to call these floors "hanging places." "Can we call them monumental?" asks Grabrijan, later answering the question himself with: "monumental, explained Le Corbusier once, are only those creations [buildings] with a clear form that come together in one whole." (Grabrijan 1955) So the answer is yes, we can call them monumental because they allow a clear, pure form to come together in a single whole that is the Macedonian house. Grabrijan then poses the question: "Ask yourself, wasn't Le Corbusier using the same elements in his villas"? (Grabrijan 1955)

\subsection{The hangar houses}

Further similarities are to be found in the plasticity of the "space architecture." Grabrijan compares Ohrid's kiosks that "fly" like airplanes in the air with Le Corbusier's "air architecture" and with Nemours: "Looking at the hanging houses on the steep terrain in Macedonia, which hang one above the other, we have to think in Le Corbusier's Nemours" (Grabrijan 1955). For Grabrijan, the most important point is the resemblance of the "hangarhouses" in Ohrid or Struga to Le Corbusier's solutions in Pessac (1925), and his workers' housing in Barcelona (1933). Grabrijan argues that the problems with which Le Corbusier and the master builders in Macedonia had to deal with were the same; that is two long sides of the house were not available for openings, and a minimum amount of surface was available for "both architects" to come to a functional solution for the house. Comparing the houses of Ohrid and Struga with those in Pessac and in Barcelona, Grabrijan points out similarities in the ground floor plans, where the functional concept of the ground floor, entails simplicity and a high level of freedom in their spatial organization. Neither the master builder nor Le Corbusier, explains Grabrijan, won't foresee the use of corridors or free spaces meant, only for circulation, independent of other functions. "Judge for yourself whether these houses [the Ohrid fisherman's house and the Struga gipsy house] are that far from Le Corbusier's workers' houses in Pessac and Barcelona", declares Grabrijan, insinuating that there is an analogy between "both architects." (Grabrijan 1955)

\subsection{The concept of the Minimal House}

Grabrijan further sees a similarity between the Macedonian house and Le Corbusier's minimal houses: in both cases, external stairs are placed in the front of the terrace. To make this point, Grabrijan, uses the example of a house from Velesi, along with photographs from Tetova and Struga, showing how one flight of stairs is placed beside the exterior wall of the house. Comparing examples of Macedonian minimal houses with Le Corbusier's designs Grabrijan explains: "Le Corbusier organizes the household functions on the ground floor of his minimal house and rais es the areas for dwelling up to the first floor. To enter the house, he places a flight of stairs beside the exterior wall, as did the master builders in the Macedonian minimal houses." Le Corbusier, according to Grabrijan, speaking about the problem of using the stairs, once explained:"these stairs beside the exterior wall of the house constitute a tremendous architectural element." (Grabrijan 1955)

\subsection{The double-height space}

Elsewhere in The Macedonian house Grabrijan thinks that the gallery is yet another architectural element used both by the master builders and Le Corbusier. Grabrijan quotes Le Corbusier as having said that "the house can never be minimal, but rather some functions have to take up smaller areas, however its heart should not be a chicken-coop, it has to be 'a space'." And Grabrijan asserts that the gallery is the element forming the heart of the Macedonian house. Grabrijan claims that Le Corbusier places rooms around the living-room in the same way as the master builders use the chardak in Macedonian houses, and that Le Corbusier's living-room is indeed the same thing as the Macedonian chardak. Comparing the section of the unbuilt Villa Baizeau, Carthago (1928) with that of a Macedonian house (Fig. 58, 59, 60), Grabrijan concludes that Le Corbusier "already knew of this particular problem." He suggests: "Analyze the gallery in houses in Ohrid and Struga, around which are placed other rooms, and you arrive at Le Corbusier's Weissenhof building in Stuttgart or Maison Cook in Paris." (Grabrijan 1955) 


\subsection{The architectural promenade}

Grabrijan also spoke about the promenade architecturale in Macedonia: "You begin by passing through the trem on the ground floor, inside the trem there is an open stairs that leads you to the chardak on the first floor, which is surrounded by rooms, either opening directly on to the chardak or connected to it via passages."(Grabrijan 1955). He explains that the spatial path one takes from the trem to the chardak in a Macedonian house is a promenade through space always revealing new surprises. These paths go from one side of the house to the other one: they beg in from the ground floor, pass up the stairs and go through the chardak. There are houses, explains Grabrijan, such as in Kruševo, Struga and Ohrid, where you can have three levels on one floor. Describing the promenade architecturale Le Corbusier's villa in Auteuil (1922) Grabrijan then asks: "Is this not the same promenade architecturale one sees in the houses in Struga with their double-height trems?" Then, using the same idea of the path which he claims Le Corbusier learned from Macedonian houses, Grabrijan suggests also that Le Corbusier expressed a similar theme in his exhibition pavilion in Paris from 1937.

\subsection{Other analogies}

Grabrijan has noticed other similarities between the Macedonian house and Le Corbusier's villas, for instance in the Macedonian rooms without furniture, because, as Grabrijan explains, "the only furniture one finds in the room is a bed and a chair." Furthermore, there is a similar desire for built-in furniture, "because", explains Grabrijan, "the Macedonian "dolaps" [built-in wardrobe] and "sergens" [the horizontal pole under ceilings for hanging men's clothes] are indeed Le Corbusier's furniture that he hides in the walls." (Grabrijan 1955). Grabrijan further explains that an analogy can be seen also in the heights of the spaces in the houses. The height $210 \mathrm{~cm}+30 \mathrm{~cm}+210 \mathrm{~cm}=450 \mathrm{~cm}$, which he claims is used also by Le Corbusier in his living rooms, comes from the Macedonian two-storey trem. Grabrijan claims that Le Corbusier's Modulor can be used completely in the Macedonian houses, because the master builders in Macedonia also used the human body as the basis for all their measurements.

Other similarities between the Macedonian house and the Corbusian one, according to Grabrijan, can be found in the "modernity" ground floor plan and elevations, in the independence of the inner disposition of rooms from the wall structure, in the architecture of the outer rooms, in the use of the fireplace and the brise-soleil. "Modern terraces", concludes Grabrijan, "have their origin in the chardaks and brises-soleil that were used as sun breakers." There is no doubt in Grabrijan's mind that Le Corbusier was inspired by the Macedonian way of sun protection, and argues "how else could a northern man come to the idea of using sun protection, when normally he is missing the sun all the time."

\subsection{Conclusion}

Grabrijan is more than sure that The Oriental house stops here in Macedonia, where it begins the Macedonian house, Macedonia is the red line where one house stops [the Oriental one], and begins the other one [the Macedonian one].

Grabrijan discusses even the question of Le Corbusier, being in Macedonia or not, concluding that Le Corbusier must have been influenced by the Macedonian house, which he seemed to knew, and there lays the importance of the Macedonian house. Macedonian houses, thinks Grabrijan are the ancestors of modern architecture, as they influenced the pioneer of modernism, Le Corbusier himself. "We" [the Macedonians] have contributed to the creation of modern architecture through the mediation of Le Corbusier. "In his Oeuvre Complete 1910-1929 we see sketches, chardaks (verandas) and interiors of our houses. Our old house, naked, rich with the sun, air and green surfaces, with large glass surfaces and with its wooden skeleton, couldn't keep away the feelings of an artistic soul like that of Le Corbusier, who will then demand modern architecture to contend with the same values" helps here Tomoski (Tomoski 1960).

\section{Discovering the Turkish house, Sedat Hakki Eldem and Asim Eyup Kömürcüoglu}


Some $1500 \mathrm{~km}$ away (east), in today's Turkey, authors through their works presented what was built during the past time. One of the earliest of them is Sedat Hakki Eldem and his book Turk Evi Plan Tipleri, which goes back to the 1930s, are one of the most important one.

Eldem through his research, attempted to go back to the origins of typologies in their historical vernacular existence. He's diverging his well-studied houses in two different groups: one is flat-roofed, white-washed house with a West Anatolian or even Mediterranean connotation; the other one, a decisively Central Anatolian house exhibiting the language of mud brick or adobe as the primary material of the region. Eldem's preferred Anatolian house with the traditional plan features and horizontal window proportions of the 17th century Amacazade Köprülü Hüseyin Pasa Yali (Fig.3), was an all-time favorite of Eldem's (Bozdogan et al. 1987).
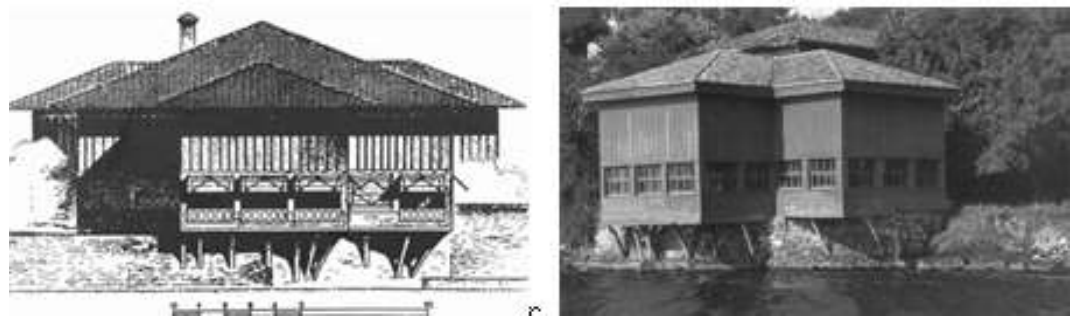

Fig.3. Amacazade Köprülü Hüseyin Pasa Yali (1699)

According to Eldem's research of the last group, we recognize his attempt to present this specific house typology based in Avlu (trem) as main element of the house. He is willing to determine the avlu as an element surrounded by other rooms, and the stairs that lead to the first floor where the Divan (chardak) is the key element of the floor. Eldem argues that due to the climate there is a division of the living areas through the different levels of the house; the winter living areas organized on the massive ground floor constructed of stone, and in the summer living areas organized on the upper floor constructed of a wooden frame, and organized around the divan (Eldem 1954).

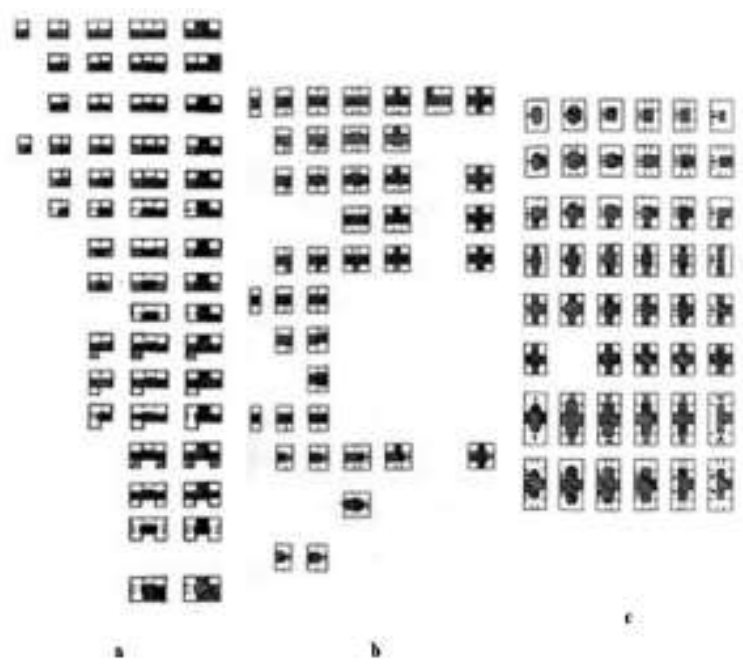

Figure 4. The matrix of Planimetric Organizations of Turkish House according to Eldem;

a) plan type with an outer sofa; b) plan type with an inner sofa; c) plan type with a central sofa

Through his many examples he brings us a variety of plans (floor) qualities. In his study Eldempresents floor plans that are irregular in the first level, than, they attempt to become regular in form, using the so-called Cikma Konstruktion, that is the way of 'expending' the floor surface of the house through the console made by wooden framework The wooden frame work, a high quality of a solid house structure is the solution on the hand of the master in Turkey, to get the most of the floor and spatial flexibility. 
Knowing and using this structure- all made by wood, the one [the master] was able to build the house where its functionality and philosophy were the main achievements.

The house Eldem is presenting in Turkey is characterized with the horizontal repetition of the vertical windows of 1:2 proportions. The usage of e great number of windows on the walls, tells the desire of the house inhabitants for street view and the light. According to Eldem's explanation, the horizontal repetition of vertical frames, are indeed the vernacular examples of the Turkish house.

The great number of the windows used by the local master goes to the final act of creating the house as a whole: full of lightness, transparency and modular logic (Eldem 1954).

Eldem has noticed that the house in general is a 'non occupied space' because there is almost no furniture inside, a space build in human scale where one can seat, meditate, rest or work. Indeed, the house is huge, thanks to the proportions used by the master when he builds the house.

Design elements such is minimal space occupied by the house and the promenade architectural are two idioms Eldem finds in the houses he studies. Houses that contain the philosophy of the Turks everyday life, are small and huge at the same time, moreover according to Eldem a Turkish House is a generic term applied to a house type, based on a wooden framework, with highly standardized plans and architectural elements.

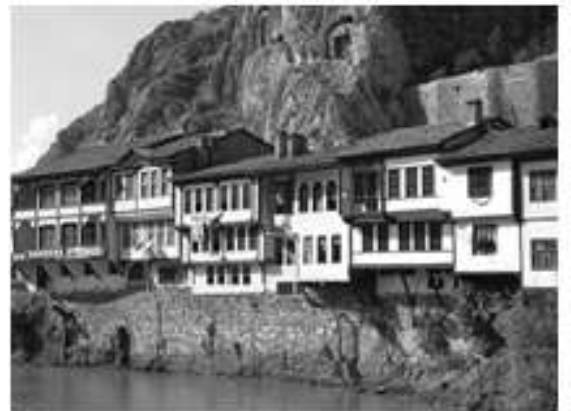

Amasys Turkey

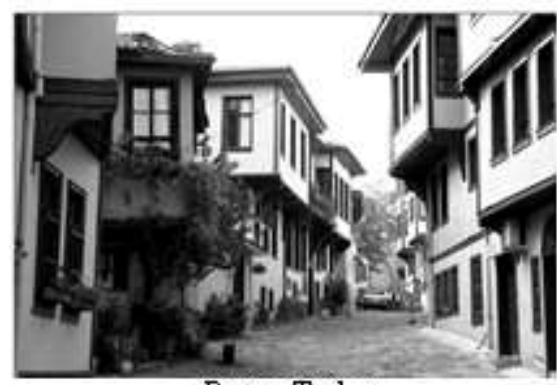

Bursa, Turkey

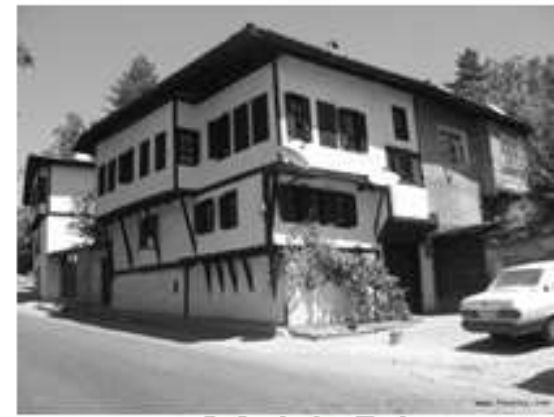

Safranbolı, Turkey

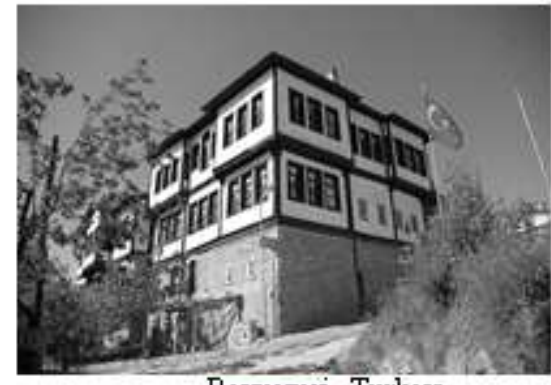

Bergazari Turkey

Fig.1. Old Turkish Houses in different cities around Turkey

Another author, Eyup Asim Kömürcüoglu, in his book Das Alttürkische Wohnhaus, [The Old Turkish House], discuses about the everyday life of the Turks, and how indeed the everyday life has been used as a motif, organizing the house floors in Turkey. Different position of seating, eating and expecting guests, makes different floor levels in the house. That is why, states Kömürcüoglu, in one single floor in the house we find even three different levels, for each purpose one level to be used.

Kömürcüoglu, thinks that the climax and the way the master was using the house elements, such is the divan, avlu, and the roof makes the Turkish house very special. Especially he argues about the possibility of making the roof as a shadow creator in the façade of the house, where the sun 'attacks' the house during the long day. The same roof will be used for the protection of the façade from rain.

Kömürcüoglu concluded that the house in Turkey is built from stone and mud, mostly the ground floor, above which the house continues to grow vertically all made by wood. The wooden structure allows the flexibility in floors, in façade, and the furniture.

Examples of floor plans, presented by Kömürcüoglu, are the most significant examples of how the master did manage the terrain during the 'planning' process of the house. We recognize very well analyzed circumstances where the master places the house, makes the ground floor very small, and then 
after he has lifted his house above the ground floor, he will use his 'saçak' construction and his 'çikma' construction (Kömürcüoglu 1966) to correct the irregularity of the ground floor, caused by the terrain, than to enlarge the surface of the next floor, where he organizes his 'harem' and 'selamlyk'.

Kömürcüoglu is convinced that the best description of the Turkish house is that the Turkish house is a conglomerate of the high quality architectural elements, such as the flexibility of plan and structure, philosophy of everyday life realized through architecture, a play of cubes, shadow and the light, altogether brought in the Turkish house as a whole.

\subsection{Conlcusion}

Table 1. Important elements in Macedonian and Turkish Houses - Comparative table

\begin{tabular}{ll}
\hline $\begin{array}{l}\text { Elements of Macedonian } \\
\text { according to above mentioned authors }\end{array}$ & $\begin{array}{l}\text { Elements of Turkish House according } \\
\text { to Turkish authors }\end{array}$ \\
\hline chardak & $\begin{array}{l}\text { divan } \\
\text { asymmetry of ground floor }\end{array}$ \\
irregularity of ground floor \\
the erker & lightness and transparency \\
bonkruk structure & cikma construction \\
human scale & bondruk structure \\
the trem & human scale architecture \\
flexibility of the first floors & avlu \\
& spatiality and flexibility
\end{tabular}

Elements that describe the Turkish house: the avlu, divan, cikma construction, the horizontal wooden window, the irregularity of ground plan, the geometry used as a tool to come to the order, the human scale architecture, the lightness and the transparency, the spatiality and flexibility, the building materials, are indeed the same as the elements described the Macedonian house. Their function, philosophy and usage were known and applied by the master in Turkey long before they were spread and used in Macedonia.

\section{Dialogue with modernism}

Searching the analogy between the Turkish house and the name of Le Corbusier (same as Grabrijan did between the Macedonian house and Le Corbusier) we have to mention some of the Le Corbusier's biographers.

Giuliano Gresleri selected, arranged and published Le Corbusier's notes from his journey through the central Balkans and Asia Minor in 1911. His book Le Corbusier; Reise nach dem Orient, contains detailed notes about Le Corbusier's travels in the Balkans, for example cities that he visited in Serbia, then his passage to Romania, his stay in the region of Arbanasi, Shipka, Kazanluk, Veliko Trnovo etc. in Bulgaria, his arrival in Istanbul and at the end his stay in Thessalonica, before he took the road back to La Cheaux-de-Fonds, this time via Italy (Gresleri 1991).

The second of Le Corbusier's biographers suggested by Madame Trehin was Ivan Žaknić who also writes about Le Corbusier's Voyage through the Balkans in 1911. In his book there are details described Le Corbusier's passage through the Balkans and his final destination- Turkey, exactly the city of Istanbul (Žaknič 1987).

In Le Corbusier, The Noble Savage, Adolf Max Vogt agrees to the effect that without the oriel principle, the Villa Stein and the Wiessenhofsiedlung could not have been conceived. Vogt describes the oriel principle, or as he calls it the "Çikma construction", as a Turkish element that had been used in architecture for a considerable time. Vogt believes that Le Corbusier got this element from houses he was sketching along the Bosphorus in 1911 during his stay in Istanbul (Vogt 1998). Unlike Vogt, Giuliano Gresleri states in Le Corbusier; Reise nach dem Orient (1991) that Le Corbusier had studied the oriel principle in Tarnovo in Bulgaria, where he sketched houses with this particular element. On the other hand, According to Vogt, Le Corbusier found an architectural configuration in which walls are replaced with columns in Istanbul as well (Vogt 1998). Vogt is able to show that Le Corbusier studied the pilotis of the Kiosks or the pavilions in 1911 and claims that without this experience, the 
Villas in Carthage and Poissy could not have been built. It would have been the Orient where Le Corbusier studied the pilotis principle. Vogt thinks that the Third Point- the fenetre en longueur- was developed by Le Corbusier by analyzing the pavilions along the banks of the Bosphorus in 1911. Furthermore, the pavilions gave the inspiration for two other of the five points: the pilotis and the façade libre

\subsection{Conclusion}

Le Corbusier visiting, staying and studying the old houses in Turkey is more likely to have been influenced by what he saw back in 1911, and the analogy between the works of Le Corbusier and the Turkish house it comes from that part of his 'education'. Shortly, Le Corbusier is influenced from the Turkish house, however not the Macedonian one.

\section{General Conclusion}

- It is plausible to conclude that there might be a Macedonian elements in the houses build in Macedonia, simply because the same 'Macedonian' elements miss their originality, they are used in otherplaces too, even before the same ones have been applied in houses in Macedonia (Wilde 1909). The same architectural elements are identified in Turkey- identifying the Turkish house. From here, one can not conclude that there is a Macedonian house, because analogies between houses build in Macedonia and the Turkish house is enormous.

- Le Corbusier could not have been inspired or influenced from houses build in Macedonia, simply because he never was there. There is a connection, or influence from the Orient- that is the Turkish house, because Le Corbusier was in Turkey in 1911 and studied the Turkish house in order to get some influence for the new modern architecture. From here, our conclusion will be that he had some influences from houses he saw in Turkey.

- Grabrijan conclusion that the Macedonian house presents a transition from the traditional Oriental to the modern European house is also plausible enough. Macedonia is not the border where the Oriental (Turkish) House stops, and begins the Macedonian house. Grabrijan itself, who made this conclusion, is controversy with himself when concluding some time later that the Bosnian house is the imitation of the Turkish house in Balkans, establishing the link between the Turkish house and the Bosnian Oriental house (Alic 1999).

- The analogy between the Turkish houses and Le Corbusier's villas at one side, and the analogy of the houses build in Macedonia and Le Corbusier's work at the other side, confirms the analogy between houses build in Macedonia and those build in Turkey. Since the analogy is sustainable (strong) there is no doubt that houses build in Macedonia might have different elements, which at the very end can be named as national Macedonian .

\section{References}

1. Alic, Dijana. „From Ottoman house to Bosnian style: Neidhardt's design for workers' housing in Bosnia and Herzegovina (1939 to 1942)." Site Vol.1, 1999.

2. Bozdogan, Sibel, Suha Ozkan, und Engin Yenal. Sedat Eldem: Architect in Turkey. Singapore: Concept Media / Aga Khan Trust for Culture, 1987.

3. Čipan, Boris. Stara gradska arhitektura vo Ohrid. Skopje: Makedonska Kniga, 1982.

4. Deroko, Aleksandar. Folklorna Arhitektura u Jugoslaviji, Narodna Arhitektura I. Beograd:Naucna Knjiga, 1968.

5. Eldem, Sedat H. Türk Evi Plan Tipleri. Istanbul: Instanbul Teknik Üniversitesi Yani, 1954.

6. Eldem, Sedat H. „Toward a Local Idiom: A summary History of Contemporary Architecture in Turkey.“ Conservation as Cultural Survival. Philadelphia: Aga Khan Award for Architecture, 1980. 89-99. 
7. Grabrijan, Dusan. „Makedonska kukja, ili preod od stara oreintalska vo sovremena evropska kukja.“ Ljubljana, 1955.

8. Gresleri, Guiliano. Le Corbusier, Reise nach dem Orient. Zürich: Spur Verlag, 1991.

9. Haxhieva-Aleksievska, Jasmina. Merki, antropomorfnost $i$ modularni proporcii kaj starata makedonska kukja. Skopje: Studenski Zbor, 1984.

10. Kömürcüoglu, Eyup Asim. Das Alt-türkische Wohnhaus. Wiesbaden: Otto Harrassovitz, 1966.

11. Mulickoski, Petar. Kreativniot duh na makedonskata kuka. Skopje: AEA, 2000.

12. Tomoski, Sotir. Makedonska narodna arhitektura. Skopje: Tehnicki Fakultet, 1960.

13. Tomovski, Krum. „Dejnosta na majstorite graditeli od Debar.“.

14. Vogt, Adolf M. Le Corbusier the Noble Savage". Cambridge, Massachusetts, London, England: The MIT Press, 1998.

15. Wilde, H. Brussa. Eine Entwicklungsstätte türkischer Architektur in Kleinasien unter den Ersten Osmanen. Berlin: Ernst Wasmuth Verlag, 1909.

16. Žaknič, Ivan. Journey to the East. Massachussets: MIT Press, 1987 